\title{
Corrigendum: The Phonological Mapping (Mismatch) Negativity: History, Inconsistency, and Future Direction
}

\author{
Jennifer Lewendon ${ }^{*}$, Laurie Mortimore ${ }^{2}$ and Ciara Egan ${ }^{2,3}$ \\ ${ }^{1}$ School of Languages, Literatures and Linguistics, Prifysgol Bangor University, Bangor, United Kingdom, ${ }^{2}$ School of \\ Psychology, Prifysgol Bangor University, Bangor, United Kingdom, ${ }^{3}$ Department of Experimental Psychology, University of \\ Oxford, Oxford, United Kingdom
}

Keywords: event-related potentials, phonology, PMN, N400, MMN, phonological mismatch, phonological mapping, language

\section{OPEN ACCESS}

Edited and reviewed by: Valentina Cuccio

University of Messina, Italy

${ }^{*}$ Correspondence:

Jennifer Lewendon

j.lewendon@bangor.ac.uk

Specialty section

This article was submitted to

Language Sciences,

a section of the journal

Frontiers in Psychology

Received: 19 October 2020

Accepted: 15 December 2020

Published: 28 January 2021

Citation:

Lewendon J, Mortimore L and Egan $C$

(2021) Corrigendum: The

Phonological Mapping (Mismatch)

Negativity: History, Inconsistency, and

Future Direction.

Front. Psychol. 11:619241.

doi: 10.3389/fpsyg.2020.619241

\section{A Corrigendum on}

The Phonological Mapping (Mismatch) Negativity: History, Inconsistency, and Future Direction

by Lewendon, J., Mortimore, L., and Egan, C. (2020). Front. Psychol. 11:1967. doi: $10.3389 /$ fpsyg.2020.01967

In the original article, there were the following mistakes in Table $\mathbf{1}$ as published:

- Row 2, column 2. "substraced" replaced with "subtracted."

- Row 4, column 3. Information about incorrect study. Information deleted.

- Row 5. Column 2. "midline" amended to "scalp"

- Row 6. Column 2. "Late N2b (250-350 ms): distributed across scalp" deleted - irrelevant.

- Row 7: Column 2. Updated to reflect the dual-study results.

The corrected Table 1 appears below.

Corrections have also been made to the title and keywords of the original article.

The corrected title and keywords are shown below:

Title: The Phonological Mapping (Mismatch) Negativity: History, Inconsistency, and Future Direction.

keywords: event-related potentials, phonology, PMN, N400, MMN, phonological mismatch, phonological mapping, language.

The authors apologize for these errors and state that they do not change the scientific conclusions of the article in any way. The original article has been updated. 
TABLE 1 | Summary of key studies charaterizing the PMN, reported effect topographies and methodological considerations.

\begin{tabular}{|c|c|c|}
\hline References & Topography & Methodological considerations \\
\hline Connolly et al. (1990) & $\begin{array}{l}\text { Unsubtracted waves: frontocentral; Subtracted (difference) } \\
\text { waves: central }\end{array}$ & 10 participants (trials per condition unclear). \\
\hline Connolly et al. (1992) & Flat distribution across midline sites & Response not visible in averaged waveforms. \\
\hline Connolly and Phillips (1994) & Frontal, central, and parietal & * \\
\hline Van Petten et al. (1999) & Flat distribution across scalp & \\
\hline D’Arcy et al. (2000) & Early N2b (130-230 ms): parietal & \\
\hline Connolly et al. (2001) & Frontal & $\begin{array}{l}10 \text { participants (min. } 60 \text { trials per condition). Conflicting MEG } \\
\text { data acknowledged to invalidate PMN results.* }\end{array}$ \\
\hline Hagoort and Brown (2000) & Exp. 1: posterior Exp. 2: no interaction with site. & $\begin{array}{l}12 \text { participants ( } 60 \text { trials per condition). "N200" response to } \\
\text { semantic expectation violations. No isolation of phonological } \\
\text { anomaly. }\end{array}$ \\
\hline van den Brink et al. (2001) & Flat distribution across scalp & \\
\hline Newman et al. (2003) & Frontotemporal & $\begin{array}{l}\text { Early onset P300 contamination in phonological expected } \\
\text { condition. Authors could not confirm absence of PMN in this } \\
\text { condition.* }\end{array}$ \\
\hline D'Arcy et al. (2004) & Frontocentral & 10 participants (24 trials per condition). \\
\hline $\begin{array}{l}\text { Newman and Connolly } \\
\text { (2009) }\end{array}$ & Frontal and central & 13 participants (40 trials per condition).* \\
\hline
\end{tabular}

"See text for full discussion of methodological limitations.

\section{REFERENCES}

Connolly, J. F., and Phillips, N. A. (1994). Event-related potential components reflect phonological and semantic processing of the terminal word of spoken sentences. J. Cogn. Neurosci. 6, 256-266. doi: 10.1162/jocn.1994.6.3.256

Connolly, J. F., Phillips, N. A., Stewart, S. H., and Brake, W. G. (1992). Eventrelated potential sensitivity to acoustic and semantic properties of terminal words in sentences. Brain Lang. 43, 1-18. doi: 10.1016/0093-934X(92)90018-A

Connolly, J. F., Service, E., D'Arcy, R. C. N., Kujala, A., and Alho, K. (2001). Phonological aspects of word recognition as revealed by high-resolution spatio-temporal brain mapping. NeuroReport 12, 237-243. doi: 10.1097/00001756-200102120-00012

Connolly, J. F., Stewart, S. H., and Phillips, N. A. (1990). The effects of processing requirements on neurophysiological responses to spoken sentences. Brain Lang. 39, 302-318. doi: 10.1016/0093-934X(90)90016-A

D'Arcy, R. C. N., Connolly, J. F., and Crocker, S. F. (2000). Latency shifts in the N2b component track phonological deviations in spoken words. Clin. Neurophysiol. 111, 40-44. doi: 10.1016/S1388-2457(99)00210-2

D’Arcy, R. C. N., Connolly, J. F., Service, E., Hawco, C. S., and Houlihan, M. E. (2004). Separating phonological and semantic processing in auditory sentence processing: a high-resolution event-related brain potential study. Hum. Brain Mapp. 22, 40-51. doi: 10.1002/hbm.20008

Hagoort, P., and Brown, C. M. (2000). ERP effects of listening to speech: semantic ERP effects. Neuropsychologia 38, 1518-1530. doi: 10.1016/S0028-3932(00)00052-X
Newman, R. L., and Connolly, J. F. (2009). Electrophysiological markers of pre-lexical speech processing: Evidence for bottom-up and topdown effects on spoken word processing. Biol. Psychol. 80, 114-121. doi: 10.1016/j.biopsycho.2008.04.008

Newman, R. L., Connolly, J. F., Service, E., and Mcivor, K. (2003). Influence of phonological expectations during a phoneme deletion task: evidence from event-related brain potentials. Psychophysiology 40, 640-647. doi: 10.1111/1469-8986.00065

van den Brink, D., Brown, C. M., and Hagoort, P. (2001). Electrophysiological evidence for early contextual influences during spoken-word recognition: N200 versus N400 effects. J. Cogn. Neurosci. 13, 967-985. doi: 10.1162/089892901753165872

Van Petten, C., Coulson, S., Rubin, S., Plante, E., and Parks, M. (1999). Time course of word identification and semantic integration in spoken language. J. Exp. Psychol. Learn. Memory Cogn. 25, 394-417. doi: 10.1037/0278-7393.25.2.394

Copyright (c) 2021 Lewendon, Mortimore and Egan. This is an open-access article distributed under the terms of the Creative Commons Attribution License (CC BY). The use, distribution or reproduction in other forums is permitted, provided the original author(s) and the copyright owner(s) are credited and that the original publication in this journal is cited, in accordance with accepted academic practice. No use, distribution or reproduction is permitted which does not comply with these terms. 